\title{
BENTHIC FORAMINIFERA IN BERMUDAN MANGROVE SWAMP: IMPLICATIONS FOR SEA-LEVEL STUDIES.
}

\author{
JAVAUX*, Emmanuelle J. and SCOTT, David B., Centre for Marine Geology, \\ Dalhousie University, Halifax, Nova Scotia B3H 3J5, Canada.
}

The subtropical carbonate islands of Bermuda include the most northern mangrove swamps in the Atlantic Ocean. Surface samples were studied to determine recent benthic foraminiferal distributions along a detailed transect in the Hungry Bay mangrove swamp. This is the first measured transect carried out in mangrove swamps for foraminiferal studies. A total of 57 species (20 agglutinated species) were identified.

This quantitative study of living (stained) and total foraminiferal assemblages reveals a vertical zonation of benthic foraminifera with respect to higher high water level (HHW). Two foraminiferal zones can be defined:

- Zone 2 (-57 to $-25 \mathrm{~cm} / \mathrm{HHW})$ is dominated by Trochammina inflata. Glomospira irregularis, Polysaccammina ipohalina, Textularia earlandi, and Trochammina macrescens are common. Variable amount of Trochammina salsa and Tolypammina $s p$. are also present. The calcareous species Triloculina oblonga, Rosalina floridana, Discorinopsis aguayoi, and Helenina anderseni are abundant, but cannot be used as paleoindicators of former sea levels, since they will be dissolved in subsurface peats. - Zone $1(-25 \mathrm{~cm} / \mathrm{HHW}$ to HHW) is dominated by Trochammina inflata. Miliammina fusca is common. Few Polysaccammina ipohalina, Textularia earlandi, Trochammina macrescens, and Trochammina salsa are present. Glomospira irregularis and Tolypammina sp. are absent. Thecamoebians appear at the end of the transect.

The distribution of mangrove swamp foraminifera can be used to locate former sea levels. The assemblage defining zone 1 occurs in a narrow elevation range $(25 \mathrm{~cm})$ in the highest part of the transect, and its recognition in subsurface peats could permit an accurate determination of past position of HHW levels in subtropical/tropical settings, and the production of sea-level curves.

The production of a Holocene sea-level curve for Bermuda, using benthic foraminifera as sea-level markers, could prove or disprove the global extent of a midHolocene highstand detected at higher latitudes marshes. This mid-Holocene event could serve as future analog if greenhouse effects cause critical global warming. 